\title{
IMPACT OF DIFFERENT LIGHT INTENSITY ON THE PRODUCTION OF THE PLANT NARCISSUS L. AND ITS FINANCIAL EFFECTS
}

Slobodan Popovic ${ }^{1}$ Dragan Djuranovic ${ }^{2}$, Bogdan Laban ${ }^{3}$, Mladen Ivic ${ }^{4}$, Slobodanka Jovin ${ }^{5}$, Sanda Nastic ${ }^{6}$, Zeljko Grubljesic ${ }^{7}$, Vera Popovic ${ }^{8}$

*Corresponding author E-mail: slobodan.popovic49@gmail.com

A R T I C L E I N F O
Original Article
Received: 04 April 2018
Accepted: 23 October, 2018
doi:10.5937/ekoPolj1804359P
UDC 336:[631.443.1+582.573.21]

Keywords:

Narcissus L., light intensity, financial effects

JEL: D29, D53, C50

\begin{abstract}
A B S T R A C T
Plant production monitoring should be conducted taking into consideration agrarian, economic and other factors. The authors of the paper point out the importance of the intensity of light on plant growing in predominantly urban growing conditions. The authors conducted an experimental research on Narcissus L. The focus was on 8 physical parameters of cultivated plants that are compared to average actual prices on the market of the Republic of Serbia. The contribution of authors is in pointing out an individual physical plant parameter with a decisive impact on its price. Narcissus L. growing under lower natural light intensity indicates that the biggest impact on plant price is that of the flower diameter $(\beta=.555, \Pi \leq .001)$. Plant growing under higher light intensity has an impact on its price predominantly on the basis of the flower diameter $(\beta=2.947, \mathrm{p} \leq .001)$ and stalk diameter $(\beta=2.947, \Pi \leq .001)$.
\end{abstract}

(C) 2018 EA. All rights reserved.

1 Slobodan Popovic, PhD, Faculty of Economics and Engineering Management, Cvecarska 2, Novi Sad, Serbia, Phone: +381 640483 563, slobodan.popovic49@gmai.com, ORCID ID https://qa.orcid.org/0000-0002-7884-2051

2 Dragan Djuranovic, PhD, Economic Faculty Subotica, Segedinski road 9-11, 24000 Subotica, Serbia, +381 024/628-000, gandra.dj@hotmail.com, ORCID ID https://qa.orcid.org/0000-0003-1218-4305

3 Bogdan Laban PhD, City administration of the City Subotica, Trg Slobode 1, 24000 Subotica, Serbia +381 +381 24626 888, bogdanl.su@gmail.com, ORCID ID (https:// qa.orcid.org/0000-0002-3730-0125

4 Mladen Ivic, PhD, University of Business Engineering and Management Banja Luka, Faculty of Economics, 78000 Banja Luka, Bosnia and Hercegovina, ivic.mm81@gmail. com, ORCID ID https://qa.orcid.org/0000-0002-4322-3859

5 Slobodanka Jovin PhD, Professional Studies, High Business School of Novi Sad, Vladimira Perica Valtera 4, Serbia, boba_jovin@yahoo.com, ORCID ID https://qa.orcid.org/0000-0003-4312-4532

6 Sanda Nastic, PhD, JKP Vodovod i kanalizacija, Novi Sad, Masarikova 17, 21000 Novi Sad, Serbia, Phone: 0214888 3333, sanda.nastic@vikns.rs, ORCID ID https://qa.orcid. org/0000-0002-9500-6629

7 Zeljko Grubljesic PhD, PIM University Banja Luka, Banja Luka, Despota Stefana Lazarevica BB, Bosnia and Hercegovina, zeljko@directbox.com, ORCID ID https:// qa.orcid.org/0000-0002-4056-6039

8 Vera Popovic, PhD, Institute of Field and Vegetable Crops, Maksim Gorkog No. 30, Novi Sad, Serbia, vera.popovic@ifvens.ns.ac.rs, ORCID ID https://qa.orcid.org/0000-0001-6032-6457

http://ea.bg.ac.rs 


\section{Introduction}

Numerous authors refer to blooming of Narcissus L. as a sign of arrival of spring (Kandeler and Ullrich 2009; Tooke and Battey 2010; Boanca et al. 2014). Grown in urban conditions, it is exposed to natural light of different intensity (Popović et al. 2014).

The genus Narcissus L. includes approximately 50 species (Simón-Porcar 2015) growing in vast habitats (Arroyo and Barrett 2000). Increase in daily temperatures triggers growth processes in Narcissus L., (Rudnicki and Nowak 1976; Hobson and Davies 1977; Horton and Ruban 2005).

The study conducted supplements the research on the impact of light on the plant (Narcissus L.), (Chen 1969; Briggs and Christie 2002; Sun et al. 2005; Devlin et al. 2007; Folta and Maruhnich 2007; Loreto et al. 2009; Albert et al. 2009). A visible result of growing plant Narcissus L. is its flower, although there are other measurable properties (Rønsted et al. 2008).

The principal aim of this paper is to present the impact of light of different intensity on the plant (Narcissus L.) growing. The other aim of the authors is to compare the effects of 8 chosen parameters of the plants under observation on their market price. The parameters chosen by the authors are those corresponding to visual requirements of customers.

The authors tested morphological plant properties by selecting 8 parameters (flower diameter, stem length, stem diameter, leaf length, leaf width, above-ground plant mass, bulb diameter and bulb mass). More productive plants have higher price, which is in line with the paper published by the authors (Popović et al. 2017a), stating the importance of real valuation. The expectations of the authors were that plants grown in area exposed to higher intensity light $(2000 \mathrm{~lx})$ would be more competitive than those grown under lower intensity light (1000 lx) in open-air urban areas.

The authors' principal expectations were that in both cases of plant growing, out of the 8 selected parameters, the size of flower would be prevailing in determining the marketability of the plants grown. The authors expected that, out of the selected parameters measured, a big effect would be of those that could be visually evaluated by customers. When plants grown in the shade were concerned, the expectations were that plants would be less competitive, with smaller flowers and lower values of the 7 tested parameters.

The experiment was conducted in the open, on two land plots, with the distance of 30$50 \mathrm{~m}$ between them, continuously exposed to different light intensity. Measurements showed that light intensity differed $100 \%$, as the first plot was in the shade of park trees and urban furniture. Narcissus L. bulbs, $12 / 14 \mathrm{~cm}$ in circumference, were planted in soil of the following properties: $\mathrm{pH}$ in $\mathrm{KCl}=6.98$ in $\mathrm{H}_{2} \mathrm{O}=7.46, \mathrm{CaCO}_{3}$ in percentage terms was 3, while humus in percentage terms was 3.86 . 100 bulbs were planted in each plot, plus $20 \%$ reserve bulbs in two parallel rows, in $15 \mathrm{~cm}$ deep holes, with 7.5 $\mathrm{cm}$ distance between two bulbs, and the distance between two rows of bulbs of $10 \mathrm{~cm}$. 
The results are analyzed by applying the arithmetic mean method with standard deviation, using the one-way variance analysis (ANOVA) and regression analysis. The results of the first regression analysis show that for plants grown in the shade (1000 $1 \mathrm{x})$, out of 8 selected parameters, the biggest effect is that of flower diameter $(\beta=.555$, $\mathrm{p} \leq .001)$, whereas a lesser contribution is that of stem diameter $(\beta=.274, \mathrm{p} \leq .001)$ and length $(\beta=.250, \mathrm{p} \leq .05)$. The results of the second regression analysis show that for plants grown under higher light intensity (2000 1x) the biggest effect is that of stem diameter $(\beta=2.947, \mathrm{p} \leq .001)$ and flower diameter $(\beta=-2.664, \mathrm{p} \leq .001)$, and the smallest is of bulb mass $(\beta=.286, \mathrm{p} \leq .01)$.

On the basis of the above stated, we developed three hypotheses H1-3. H: 1 Plant (Narcissus L.) growing under conditions of different natural light intensity results in plants of different output values. H: 2 growing the plant (Narcissus L.) under conditions of different natural light intensity and comparison to average retail prices show significant differences. H: 3 Plants (Narcissus L.) grown under conditions of higher light intensity have greater values of the tested parameters and therefore a higher price.

Finally, we focused our activities on determining an individual contribution of each of the 8 selected parameters of plants grown under different light intensity, as by a different organization of plant production it is possible to improve parameter values in the future.

\section{Material and methods}

The experiment was conducted in the City of Novi Sad area (latitude $45^{\circ} 20^{\prime}$, longitude $\left.19^{\circ} 51^{\prime}\right)$, more precisely, approximately 1000 meters from the entrance to Novi Sad plant nursery (north of Serbia). The average annual air temperature at the site is $10.9^{\circ}$ $\mathrm{C}$, with average precipitation of approximately $578 \mathrm{~mm}$ and altitude of $86 \mathrm{~m}$. The activities were carried out in the period from 1 November 2013 to 3 March 2016, when values of the 8 chosen parameters were measured.

The experiment commenced by planting bulbs of 6-7 cm in diameter in the soil from which weed was mechanically removed and which was not fertilized or chemically treated since 1963. The two plots were close to each other (approx. $35 \mathrm{~m}$ distance), and they were continuously exposed to different sunlight intensity during the day. The first plot received $100 \%$ less sunlight (due to trees and urban furniture of up to $0.5 \mathrm{~m}$ height) than the second. That was confirmed by measurements of light intensity in the part of day with the most intensive sunlight on both plots. Measurements of light intensity were made by a manual device along both plots on every 0.5 to $0.8 \mathrm{~m}$, and the device tolerance was $3 \%$.

Light intensity measurements were made at 12, 14 and 16 hours on 30 March 2014, 30 March 2015 and 30 March 2016. Control measurements were made 30 days before and 30 days after the period under consideration in the same time intervals. At each measurement the natural light intensity on the first plot was 1000 lx, and on the second 2000 lx. 
The first aim of the study was to determine the impact of different natural light intensity on cultivated plants on the basis of their morphological changes, by monitoring 8 physical values of the selected parameters. The second aim was to disclose the significance of changes in 8 selected parameters in terms of retail prices in the Republic of Serbia on the three selected days in the three years under observation (2014-2016). The third aim was to determine which of the 8 selected parameters had the biggest impact on retail price.

Data obtained in the experiment were processed using the arithmetic mean analysis. The authors also used the variance analysis (ANOVA) to compare the groups. In addition to that, two regression analyses were made to test the relationships.

\section{Results}

\section{Impact of light on morphological properties of plants}

Following the published three-year experiment (from 1 November 2013 until 30 March 2016) conducted in an open-air urban area under conditions of significantly different natural light intensity; the obtained results on the grown plants indicate significant changes in plant appearance.

The results of the described physical measurements of the selected parameters of the grown plants are presented using the arithmetic mean of the 8 plant parameters in question as follows:

Figure 1. Average values of stem length and leaf length (mm)

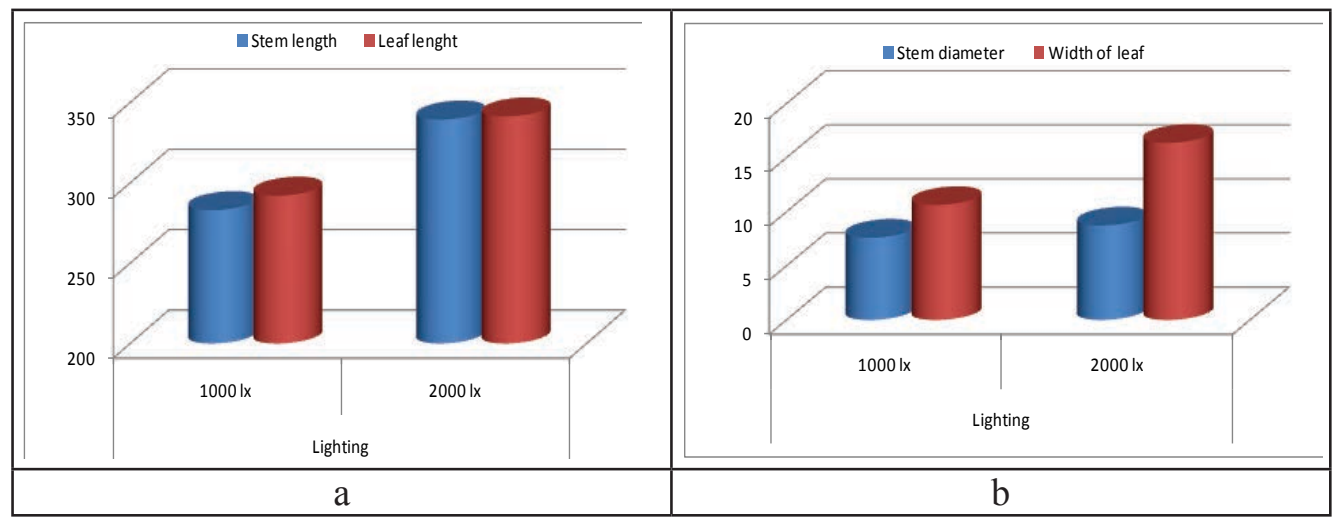




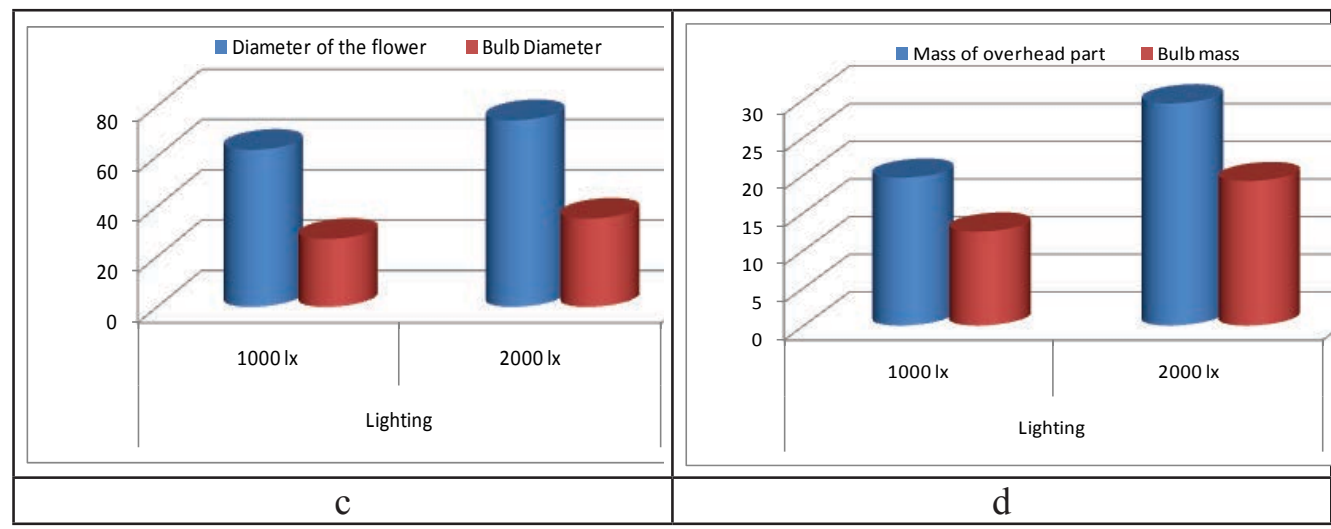

Note: (a), stem diameter and leaf width, mm, (b), diameter of the flower and bulb diameter, mm, (c), mass of overhead part and bulb mass, g, (d), grown under different intensities of light intensity

Source: author's own research.

Further research conducted by the authors on the impact of light on plant morphological properties (Table 1) is shown through 8 parameters of the arithmetic mean and standard deviation. The results of arithmetic means have greater values, i.e. plants have greater physically measured values in all 8 parameters in conditions of being grown under higher intensity light (2000 lx compared to 1000 lx in the shade). We applied the oneway analysis of variance to compare the arithmetic means of the parameters. Value $p$ $=.000$ is obtained with all 8 parameters, indicating significant differences in the plants grown. The biggest value, $\mathrm{F}=530.174$ is obtained for flower diameter parameter and $\mathrm{F}$ $=519.877$ for stalk length parameter which indicates that these two parameters are the most pronounced of all parameters involved.

Table 1. Results obtained by comparing physical values of parameters (ANOVA)

\begin{tabular}{|l|c|c|c|c|c|c|}
\hline \multirow{2}{*}{ Parameters } & \multicolumn{2}{|l|}{ Arithmetic mean } & \multicolumn{2}{|c|}{$\begin{array}{l}\text { L t a n d a r d } \\
\text { deviation }\end{array}$} & \multirow{2}{*}{ F } & p \\
\cline { 2 - 5 } & \multicolumn{5}{|c|}{ Light intensity } \\
\cline { 2 - 5 } & $1000 \mathrm{~lx}$ & $2000 \mathrm{~lx}$ & $1000 \mathrm{~lx}$ & $2000 \mathrm{~lx}$ & & \\
\hline $\begin{array}{l}\text { F 1 o w e r } \\
\text { diameter }\end{array}$ & 62.50 & 74.30 & 4.24 & 7.80 & 530.174 & .000 \\
\hline Stalk length & 282.93 & 339.33 & 20.41 & 37.67 & 519.877 & .000 \\
\hline Stalk diameter & 7.60 & 8.73 & .89 & 1.65 & 109.659 & .000 \\
\hline Leaf length & 291.93 & 341.27 & 35.32 & 55.47 & 168.809 & .000 \\
\hline Leaf width & 10.62 & 16.37 & 2.20 & 5.71 & 264.238 & .000 \\
\hline $\begin{array}{l}\text { Plant above- } \\
\text { soil part mass }\end{array}$ & 19.63 & 29.49 & 8.26 & 9.35 & 187.238 & .000 \\
\hline Bulb diameter & 26.98 & 35.10 & 3.80 & 7.30 & 292.023 & .000 \\
\hline Bulb mass & 12.47 & 19.17 & 2.71 & 5.21 & 389.786 & .000 \\
\hline
\end{tabular}

Source: author's own research. 


\section{Plant pricing}

The impact of the selected parameters of plants grown under different light intensity on their pricing in the tree days of measurement in March in the 2014-2016 interval, is shown in Fig. 2

Figure 2. Average prices realized on the retail market for plants grown at different light intensity.

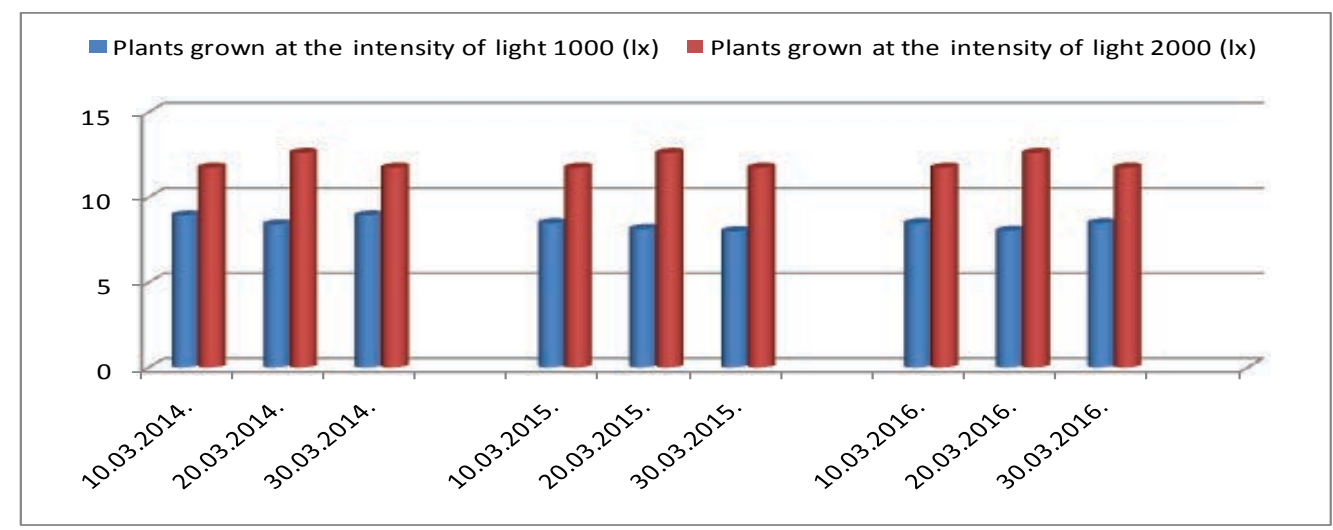

Source: author's own research.

Results of relations of prices and plants grown are presented in Table 2. The obtained plant parameter measurement results are $p=.000$. Throughout the research period the results of the one-way analysis of variance (ANOVA) indicate that prices of plants grown in shade are lower.

Table 2. Results obtained by comparing prices and parameters (ANOVA)

\begin{tabular}{|l|c|c|c|c|r|r|}
\hline \multirow{3}{*}{ Prices at day/year } & \multicolumn{3}{|l|}{$\begin{array}{l}\text { Arithmetic mean } \\
\text { deviation }\end{array}$} & \multirow{2}{*}{ F } & \multirow{2}{*}{ p } \\
\cline { 2 - 5 } & \multicolumn{3}{|c|}{ Light intensity } & \\
\cline { 2 - 5 } & $1000 \mathrm{~lx}$ & $2000 \mathrm{~lx}$ & $1000 \mathrm{~lx}$ & $2000 \mathrm{~lx}$ & & \\
\hline 10 March 2014 & 8.93 & 11.73 & .99 & 1.69 & 607.645 & .000 \\
\hline 20 March 2014 & 8.40 & 12.60 & 1.50 & 2.54 & 607.645 & .000 \\
\hline 30 March 2014 & 8.93 & 11.73 & .99 & 1.69 & 607.645 & .000 \\
\hline 10 March 2015 & 8.47 & 11.73 & .99 & 1.46 & 1.025 .570 & .000 \\
\hline 20 March 2015 & 8.13 & 12.60 & 1.50 & 2.11 & 891.835 & .000 \\
\hline 30 March 2015 & 8.00 & 11.73 & .99 & 1.95 & 869.012 & .000 \\
\hline 10 March 2016 & 8.47 & 11.73 & .99 & 1.46 & 1.025 .570 & .000 \\
\hline 20 march 2016 & 8.03 & 12.60 & 1.49 & 2.58 & 702.809 & .000 \\
\hline 30 March 2016 & 8.47 & 11.73 & .99 & 1.46 & 1.025 .570 & .000 \\
\hline
\end{tabular}

Source: author's own research. 


\section{First regression analysis}

We went further in our research to determine which of the 8 selected parameters of plants grown in the shade $(1000 \mathrm{~lx})$ prevails individually in retail price setting (Tab.3 and Tab.4).

Table 3. First regression analysis of relations between the average retail price and physical values of the selected parameters of plants grown under light intensity of $1000 \mathrm{~lx}$

\begin{tabular}{|c|c|c|c|c|c|c|c|c|}
\hline & $\begin{array}{c}\text { Sum of } \\
\text { squares }\end{array}$ & $\begin{array}{c}\text { Degree of } \\
\text { freedom }\end{array}$ & $\begin{array}{c}\text { Average } \\
\text { square }\end{array}$ & $\mathbf{F}$ & $\begin{array}{c}\text { Significance } \\
\text { level }\end{array}$ & $\mathbf{R}$ & $\mathbf{R}^{\mathbf{2}}$ & $\begin{array}{c}\text { Adjusted } \\
\mathbf{R}^{\mathbf{2}}\end{array}$ \\
\hline Regression & 497.708 & 8 & 61.46 & 34.549 & .000 & .698 & .487 & .473 \\
\hline
\end{tabular}

Source: author's own research.

Table 4. Values of selected parameters as predictors of average retail price of plants grown at light intensity of $1000 \mathrm{~lx}$

\begin{tabular}{|c|c|c|c|c|c|}
\hline \multirow{2}{*}{ Predictors } & \multicolumn{2}{|c|}{ Non-standardized ratios } & $\begin{array}{c}\text { Standardized } \\
\text { ratios }\end{array}$ & \multirow{2}{*}{ Significance level } \\
\cline { 2 - 3 } & $\mathrm{B}$ & Standard error & Beta & & \\
\hline Constant & -2.398 & .889 & & -2.698 & .007 \\
\hline Stalk length & .012 & .005 & .250 & 2.241 & .026 \\
\hline $\begin{array}{c}\text { Flower } \\
\text { diameter }\end{array}$ & .131 & .018 & .555 & 7.338 & .000 \\
\hline Stalk diameter & .305 & .091 & .274 & 3.365 & .001 \\
\hline Leaf length & -.008 & .005 & -.234 & -1.719 & .087 \\
\hline Leaf width & -.093 & .061 & -.112 & -1.543 & .124 \\
\hline $\begin{array}{c}\text { Above-ground } \\
\text { part mass }\end{array}$ & -.013 & .017 & -.059 & -.773 & .440 \\
\hline Bulb diameter & .029 & .023 & .115 & 1.246 & .214 \\
\hline Bulb mass & -.031 & .038 & -.087 & -.812 & .417 \\
\hline
\end{tabular}

Source: author's own research.

The first regression analysis of the plant grown at $1000 \mathrm{~lx}$ indicates the biggest effect of flower diameter on the flower retail price $(\beta=.555, \mathrm{p} \leq .001)$, whereas somewhat lesser effect is that of stalk diameter $(\beta=.274, \mathrm{p} \leq .001)$ and length $(\beta=.250, \mathrm{p} \leq .05)$.

\section{Second regression analysis}

The research continued in order to determine which of the 8 selected parameters of the plant grown under 2000 lx light intensity has the biggest individual effect on retail price setting (Tab. 5 and Tab. 6). 
Table 5. Second regression analysis on relationship between the average retail price and selected parameters of plants grown at 2000 lx light intensity

\begin{tabular}{|l|l|c|l|c|c|c|c|l|}
\hline & $\begin{array}{l}\text { S quare } \\
\text { sum }\end{array}$ & $\begin{array}{c}\text { Degrees } \\
\text { of } \\
\text { freedom }\end{array}$ & $\begin{array}{l}\text { Average } \\
\text { square }\end{array}$ & $\mathbf{F}$ & $\begin{array}{l}\text { Significance } \\
\text { level }\end{array}$ & $\mathbf{R}$ & $\mathbf{R}^{\mathbf{2}}$ & $\begin{array}{l}\text { Adjusted } \\
\mathbf{R}^{\mathbf{2}}\end{array}$ \\
\hline Regression & 245.944 & 8 & 30.743 & 55.713 & .000 & .778 & .605 & .594 \\
\hline
\end{tabular}

Source: author's own research.

Table 6. Values of the selected parameters as predictors of the average retail price of plants grown under 2000 lx light intensity

\begin{tabular}{|c|c|c|c|c|c|}
\hline \multirow{2}{*}{ Predictors } & \multicolumn{2}{|c|}{ Non-standardized ratios } & \multirow{2}{*}{$\begin{array}{c}\begin{array}{c}\text { Standardized } \\
\text { ratios }\end{array} \\
\text { Beta }\end{array}$} & \multirow{2}{*}{$\mathbf{t}$} & \multirow{2}{*}{$\begin{array}{c}\text { Significance } \\
\text { level }\end{array}$} \\
\hline & $\mathrm{B}$ & Standard error & & & \\
\hline Constant & -7.905 & 2.072 & & -3.815 & .000 \\
\hline Stalk length & .047 & .005 & .825 & 10.404 & .000 \\
\hline $\begin{array}{c}\text { Flower } \\
\text { diameter }\end{array}$ & -.727 & .140 & -2.644 & -5.192 & .000 \\
\hline Stalk diameter & 3.846 & .580 & 2.947 & 6.635 & .000 \\
\hline Leaf length & .023 & .006 & .703 & 3.714 & .000 \\
\hline Leaf width & -.331 & .061 & -1.620 & -5.383 & .000 \\
\hline $\begin{array}{c}\text { Above-ground } \\
\text { part mass }\end{array}$ & .242 & .031 & 1.943 & 7.875 & .000 \\
\hline Bulb diameter & .351 & .046 & 1.144 & 7.642 & .000 \\
\hline Bulb mass & .123 & .045 & .286 & 2.727 & .007 \\
\hline
\end{tabular}

Source: author's own research.

The second regression analysis of the plants grown under $20001 \mathrm{x}$ indicates that the biggest effect is that of stalk diameter $(\beta=2.947, \mathrm{p} \leq .001)$ and flower diameter $(\beta=-$ $2.664, \mathrm{p} \leq .001)$, followed by the above-ground part $(\beta=1.943, \mathrm{p} \leq .001)$, leaf width $(\beta=-$ $1.620, \mathrm{p} \leq .001)$ and bulb diameter $(\beta=1.144, \mathrm{p} \leq .001)$. Somewhat smaller is the effect of stalk length $(\beta=.825, p \leq .001)$ and leaf length $(\beta=.703, p \leq .001)$ and the smallest effect is that of bulb mass $(\beta=.286, \mathrm{p} \leq .01)$.

\section{Discussion}

Our initial expectations were that there was a significant impact of light intensity on morphological features of plants grown under different natural light intensity, and we were focused on two analyses relating to the plant growing.

First, physical values of plant parameters obtained on the basis of experiment results were analyzed. The results indicate that there is a significant difference among all 8 physical parameters $(\mathrm{p}=.000)$ measured on the plants grown under different natural light intensity, which corresponds to the views of Kinoshita and Wada 2000; Kinoshita et al. 2001; Okazawa and Nishijima 2017; Tan et al. 2017. Plant growing under higher intensity light results in higher values of the 8 plant parameters, with the biggest difference in flower diameter $(\mathrm{F}=530.174)$ compared to the plants grown in the shade. 
The second observation relates to the price of plants grown under different light intensity. The obtained values of 8 parameters $(\mathrm{p}=.000)$ compared to their retail prices indicate a significant difference. Plants grown in the shade have lower retail prices. The prices were steady in the entire period in which the experiment was conducted, as illustrated in Fig. 2.

The complex observation of plant growing under different natural light intensity is made using two regression analyses, one for the plants grown at light intensity of 1000 $\mathrm{lx}$, and the other for plants grown at light intensity of $2000 \mathrm{~lx}$. We went further in our research by determining individual effects of the 8 physical parameters of the plants grown under different light intensity on retail price setting (Tab. 3 through 6). Plants grown under $1000 \mathrm{~lx}$, i.e. in the shade, have lower price, with the biggest effect of flower diameter $(\beta=.555, \mathrm{p} \leq .001)$, whereas stalk diameter $(\beta=.274, \mathrm{p} \leq .001)$ and length $(\beta=.250, p \leq .05)$ have a smaller effect. Other physical properties measured through the selected parameters do not prove to be good predictors in retail price setting. Plants grown under $100 \%$ higher natural light intensity, which is $2000 \mathrm{~lx}$, have higher prices, with the biggest effect of stalk diameter $(\beta=2.947, p \leq .001)$ and flower diameter $(\beta=-$ $2.664, p \leq .001)$ on the flower price, followed by above-ground plant part $(\beta=1.943$, $\mathrm{p} \leq .001)$, leaf width $(\beta=-1.620, \mathrm{p} \leq .001)$ and bulb diameter $(\beta=1.144, \mathrm{p} \leq .001)$, then, to a somewhat lesser extent, stalk length $(\beta=.825, \mathrm{p} \leq .001)$ and leaf length $(\beta=.703, \mathrm{p} \leq .001)$ and bulb mass $(\beta=.286, \mathrm{p} \leq .01)$ having the smallest effect.

We point out that, on the basis of obtained results, H: 1 is fully accepted, as the plants grown under different light intensity have different product-related values. H:2 is fully accepted as the results of the experiment of plant growing under different natural light intensity are obtained and the comparison of light intensity to average retail prices resulted in significant deviations. H: 3 proved to be correct, as the plants (Narcissuss L.) grown under conditions of higher intensity light have significantly bigger values of the tested parameters and therefore a higher retail price.

Our final activities were aimed at determining an individual effect of each of the 8 parameters of selected plants grown under different light intensity, as it is possible to improve parameter results in the future with different organization of plant growing. This corresponds to the other research (Williams 2010; Popović, 2014; Popović et al. $2017 \mathrm{~b}$ ). The results of the study could serve for future research activities with other plants attractive in appearance, on the basis of the survey of customer needs, the demand for which is continuously growing.

\section{Conclusion}

There is an impact of conditions of urban plant production on their actual market price. The research results show that plants grown under different natural light intensity are priced differently on the market. Plants grown under higher natural light intensity have higher retail prices. The study indicates that in case of Narcissus L. grown under lower natural light intensity, out of 8 parameters under consideration, the biggest impact on its 
price is that of flower diameter. Plant growing under higher light intensity has an impact on its price predominantly on the basis of flower diameter and stalk diameter. These conclusions can be used as a guideline to researchers in selecting the required plant properties that impact its price. The authors point out the innovation and importance of results they obtained in the study. They also emphasize that the research could be expanded to other plant species.

\section{Conflict of interests}

The authors declare no conflict of interest.

\section{References}

1. Albert N, Lewis D, Zhang H, Irving L, Jameson P. \& Davies K. (2009): Light-induced vegetative anthocyanin pigmentation in Petunia.Journal of Experimental Botany, 60:2191-2202. https://doi.org/10.1093/jxb/erp097

2. Arroyo J, Barrett S.(2000): Discovery of distyly in Narcissus (Amaryllidaceae). American Journal of Botany, 87: 748-751. https://doi.org/10.2307/2656861

3. Briggs W, Christie J.(2002): Phototropins 1 and 2: versatile plant blue-light receptors. Trends in Plant Science, 7: 204-210. https://doi.org/10.1016/S13601385(02)02245-8

4. Boanca I, Dumitras A \& Laczi E.(2014): Integrated System in Landscaping Design and Landscape Ecology: Simplicity or Complexity?. ProEnvironment, 7: 46-52.

5. Chen S.(1969): Carbohydrate Metabolism in theNarcissus Leaf. Journal of Experimental Botany, 20:302-316. https://doi.org/10.1093/jxb/20.2.302

6. Devlin P, Christie J \& Terry M.(2007): Many hands make light work. Journal of Experimental Botany, 58: 3071-3077. https://doi.org/10.1093/jxb/erm251

7. Folta K \& Maruhnich S.(2007): Green light: a signal to slow down or stop. Journal of Experimental Botany, 58: 3099-3111. https://doi.org/10.1093/jxb/ erm130

8. Hobson G and Davies J.(1977): Mitochondrial Activity and Carbohydrate Levels in Tulip Bulbs in Relation to Cold Treatment. Journal of Experimental Botany, 28:559-568. https://doi.org/10.1093/jxb/28.3.559

9. Horton P \& Ruban A.(2005): Molecular design of the photosystem II light-harvesting antenna: photosynthesis and photoprotection. Journal of Experimental Botany, 56:365-373. https://doi.org/10.1093/jxb/eri023

10. Kandeler R \& Ullrich W.(2009):Symbolism of plants: examples from EuropeanMediterranean culture presented with biology and history of art: FEBRUARY: Sea-daffodil and narcissus. Journal of Experimental Botany, 60:353-355. https://doi.org/10.1093/jxb/erp012 
11. Kinoshita T \& Wada M.(2000): Blue Light-Induced Chloroplast Relocation in Arabidopsis thaliana as Analyzed by Microbeam Irradiation. Plant Cell Physiol, 41: 84-93.

12. Kinoshita T, Doi M, Suetsugu N, Kagawa T, Wada M \& Shimazaki K.(2001): Phot 1 and Phot 2 mediate blue light regulation of stomatal opening. Nature, 414, 656-660. DOI: 10.1038/414656a

13. Loreto F, Tsonev T \& Centritto M.(2009):The impact of blue light on leaf mesophyll conductance. Journal of Experimental Botany, 60 (8):2283-2290. DOI: $10.1093 / \mathrm{jxb} / \mathrm{erp} 112$

14. Okazawa T \& Nishijima T.(2017): Effect of Low Light Intensity on Longevity of Flowering on Bedding Plants Targeted for Indoor Use. Japan Agricultural Research Quarterly: JARQ, 51(3): 279-286. DOI: 10.6090/jarq.51.279

15. Popović, S. (2014). Socio-economic factors limiting the development of agrarian, Feljton, Novi Sad. [in Serbian: Popović, S. (2014). Socio-ekonomski faktori ograničenja razvoja agrara, Feljton, Novi Sad].

16. Popović S, Tošković J \& Grublješić Ž.(2014): Environmental-Economic Model of Developing Composters in Parks, Protected Areas and City Limits in the Republic of Serbia. ProEnvironment, 7: 213-217.

17. Popović S, Novaković S, Đuranović D, Mijić R, Grublješić Ž, Aničić J. \& Majstorović A.(2017a): Application of international accounting standard-16 in a public company with predominantly agricultural activities. Economic Research-Ekonomska Istraživanja, 30:1, 1850-1864. https://doi.org/10.1080/ 1331677X.2017.1383171

18. Popović S, Jovin S, Đuranović D, Popović V, Filipović V, Munitlak-Ivanović O, Grublješić Ž, Mijić R.(2017b): The Importance of Planting Pot Marigolds (Calendula officinalis L.) in degraded public spaces from the agro-ecological and economic perspective. Contemporary Agriculture, 66(1-2): 27-31. https:// doi.org//10.1515/contagri-2017

19. Rønsted N, Savolainen V, Mølgaard P \& Jäger A.(2008): Phylogenetic selection of Narcissusspecies for drug discovery. Biochemical Systematics and Ecology, 417-422. DOI: 10.1016/j.bse.2007.12.010

20. Rudnicki R \& Nowak J.(1976):Studies on the Physiology of Hyacinth Bulbs (Hyacinthus orientalis L.): VI. Hormonal activities in hyacinth bulbs during flower formation and dormancy release. Journal of Experimental Botany, 27:303-313. https://www.jstor.org/stable/23689253

21. Simón-Porcar V, Picó X \& Arroyo J.(2015):Range-wide population genetics and variation in morph ratio in style-dimorphic Narcissus papyraceus. American Journal of Botany,102: 449-456. https://doi.org/10.3732/ajb.1400209

22. Sun Q, Yoda K \& Suzuki H.(2005):Internal axial light conduction in the stems and roots of herbaceous plants. Journal of Experimental Botany, 56 (409):191203. https://doi.org/10.1093/jxb/eri019 
23. Tan C. L, Wong N. H, Tan P. Y, Ismail M \& Wee L. Y.(2017): Growth light provision for indoor greenery: A case study. Energy and Buildings, 144: 207217. DOI: 10.1016/j.enbuild.2017.03.044

24. Tooke F \& Battey N.(2010):Temperate flowering phenology. Journal of Experimental Botany, 61:2853-2862. https://doi.org/10.1093/jxb/erq165

25. Williams, C. (2010). Principles of management, Data Status, Belgrade. [in Sebian: Williams, C. (2010). Principi menadžmenta, Data Status, Beograd]. 